\title{
A CHOICE OF LEGAL ACT DURING LAW-MAKING PROCESS
}

Mikhail B. Rumyantsev ${ }^{1}$, Vladislav Yu. Turanin ${ }^{2}$, Arsen V. Akopyan ${ }^{3}$, Dina V. Alontseva ${ }^{4}$, Olga V. Batova ${ }^{5}$ ${ }^{1}$ FGNC VNIIMP names after V.M. Gorbatova, 26, Talalikhina Street, Moscow, 109316, Russia, ${ }^{2}$ Belgorod State University, 85 Pobedy St., Belgorod, 308015, Russia, ${ }^{3,4}$ Bunin Yelets State University, 28 Kommunarov St., Yelets, 399770, Russia, ${ }^{5}$ ITMO University (Saint Petersburg National Research University of Information Technologies, Mechanics and Optics), 49 Kronverkskiy Prospekt, St. Petersburg, 197101, Russia.

Email: ${ }^{1}$ asia@ prescopus.com, ${ }^{2}$ michael.1@ prescopus.com, ${ }^{3}$ peter.seliverstov@ prescopus.com, ${ }^{4}$ editor@ prescopus.com, 5 editor@prescopus.com

\section{Article History: Received on $25^{\text {th }}$ July 2019, Revised on $01^{\text {st }}$ September 2019, Published on $12^{\text {th }}$ October 2019}

\begin{abstract}
Purpose: There is a problem of legal act choice during the law-making process considered in the paper. A method for stepby-step choice algorithm is advanced. The algorithm is associated with public relationship assessment. The public relationships to be regulated must have a certain social value.
\end{abstract}

Methodology: The method for step-by-step choice is developed based on the public relationship assessment method extracted from law books. Despite existing in law books the criteria for public regulation needs, the method for act choice itself was not elaborated. The new methodological tools to create driving law-making researches are introduced.

Result: The law-making solutions must appear from objective public relationships needs to change which are stem from the political, economic and social conditions considered. Law-making solution projects should be legally examined as well as drawn up through public discussion which can help to find optimal alternative of the solution. The problem of interrelation between harmonization and uniformization on different legal regulation levels is also marked. Self-Regulation in private law branch is represented to be maximally developed because the higher self-regulation the fewer laws, orders, regulations, and instructions to be adopted. All legal act choices should promote self-regulation as much as possible. This could reduce law-enforcement authorities' load. Legal act choice is a weak scientific field in which much is to be done.

Applications: This research can be used for the universities, teachers and education students.

Novelty/Originality: In this research, the model choice of the legal act during law-making PROCESS is presented in a comprehensive and complete manner.

Keywords: law-making, authorities, choice, comparative law, globalization, harmonization.

\section{INTRODUCTION}

The legal regulation is referred to as a complex scientific and up-built activity that relates both the assessment of law reliability for public relationships considered and the choice of legal act of appropriate power. The law-making process has to determine the objective, justice nature determined, legal regulability of public relationships as well as their need to be regulated within given social conditions by means of different norms and other law exercises forming together a legal regulation mechanism (Kong, Hoi. 2010).

The very difficult law-making solution presents a choice of legal act required for regulation of big relationship groups situated close to each other. The law books indicate that legal act has the following specifications: 1) it is issued by authorized state bodies or adopted by people directly during the referendum as the constitution says; 2 ) it contains legal norms ( the legal act enforces, cancels or changes them); 3) any legal act is empowered, saved and provided by the state; 4) it is issued in write form with précised structure and necessary attributes; 5) it is actual and legitimized ( Kremin A.E., Gulin K.A. 2017).

The legal regulation should cover the public relationships having the following specific traits: 1) They combine interests of individual persons and those of whole society; 2) These relationships include regulation of mutual interests of participants each of them partially leaves his/her interest to satisfy other relationship participants; 3) The relationships are formed based on certain rules familiar and observed by all society members; 4) Observation of the rules is carried out via state compulsories (Rybakov V.A. 2015; Solovyev S.G. 2012). The public relationships out of this range are regulated by other social norms or not regulated in general.

To carry out a legal regulation, the public relationships noted are firstly investigated to fetch out the variables ( criteria) which completely indicate needs to regulate them. These criteria include:

1. The variables indicating the provisionality of relationships:

- These are constant, typical, representable relationships existing between many people, so the individual person's behavior is not quality for provision;

- The relationships are controllable ab extra, so otherwise, it would be difficult to appoint whether person's behavior be in good manner or not; 
- The relationship permits choice one or several probable behavioral templates for participants (Werner Menski. 2006; Hojati, M., Rezaei, F., \& Iravani, M. R. 2014), which indicates the limits for an allowable pattern in which range any actions are good.

2. The variables for relationships objective needs to regulate:

a) The social value of relationship and impossibility to regulate via other social norms;

b) The appearance of law regulation deficiency, dozens of act to resolve the same question so the realization of actual legal norm is embarrassed;

c) The provisions for certain public relationships regulation provided by the Russian Constitution and other Russian legal acts as well as direct requirements of international legal acts enforced at RF territory (Sultanbekova, Z., Yergobek, K., Atemova, K., \& Koshenova, T. 2018).

Regarding the above, we can agree with foreign approach to make sociology help law-making. "From perspective of law, however, sociology's function remains more that auxiliary science" (Matandare, M. A. 2018; Nazoktabar, H., \& Tohidi, G. 2014). From this point of view, the later is, the bigger sociology law-making footprint is.

\section{METHODS}

Methodological approaches to the research are based on general scientific methods (comparison, generalization, analysis, synthesis)...

A hurdle to choose a legal act also includes law-making subject's need to take simultaneously into account many circumstances influencing the law-making solution quality and effectiveness:

1. Properties of the public relationships to be regulated; their ability to carry some functions within a specific framework defined via legal norms (The public relationships must have a property norm-of-tunability);

2. The feasibility of individual municipal law branch means for legal regulation purposes. This signifies their norm-tofeasibility indicating an ability of the legal norms to be applied to regulate given public relationships;

3. An ability of the law-making bodies themselves to legislate legal models necessary to regulate public relationships, this can be named law-ability-to-norm (Curtin, D., \& Leino, P. (2017.);

4. Consolidation in-branch law norms its basic principles, objective, nomenclature and consistent set of the provision-ofnorms aimed at the regulation of the specific similar relationship fields (property called provision-in-norm).

5. Ranking and systematicity of the law-making solutions. Ranking of the statutory acts assumes a subsequence for their location from inferior acts to the superior ones taking into account their power as well as their insubordination related to other statutory acts (Vereshchetin, V. S. (1996)).

The difficulty of legal act choice also includes that up to date it is carried out mainly via empiricism. The law-making theory has not already presented a scientifically-based approach to study the public relationships as social and economic phenomenon which needs legal regulation both from given process possibility and admissibility point of view and from the advisability point of view.

\section{RESULT AND DISCUSSION}

The difficulty of legal act choice in every case is premised on the following circumstances:

1. Law or by-law? - This problem should be firstly solved. That's solution should be grounded and drawn up from actual public relationship needs. To do this, as more as possible of available earlier acts shall be chosen and then analyzed ( For example, international instruments, conventions on given relationship range; actual Russian legal acts including Federation Subjects ' acts; foreign acts on the public relationships ranges to be regulated) (Kuznetsova, E. 2019). The incorrect solution may result that less valued social relationships would be regulated by law - it could reduce the legislation power due to disagreement between the legal acts issued and objective public realities (Lima, A., Mendes, D., \& Paiva, S. 2018). The solution to draft a less powered act instead of adopting the necessary law also seems to be unacceptable. In this case, the capability of by-law to regulate the relationships is unfeasibly set too high which leads to substitution errors both in the field of law-making subject and in by-law-making (Steunenberg, B., \& Toshkov, D. (2009).)

The criteria for the distinction between law and by-law may help to provide an appropriate solution. There is content and legal-normative criteria included those in law books.

The content criterion indicates the social value of public relationships, their stability and significance in people's relationships, the degree of their legal effect need. This means that public relationship with higher impact on national social, economic and political life should be provided with legislative framework for whereas by-relationship should be regulated via by-laws (Tushnet, M. (1972)). 
The normative and judicial criterion characterizes law and by-law legal nature. It allows estimating more precisely their abilities to provide legally different public relationships. This criterion is estimated via such variables as following: 1) legal act content compliance with RF and its subject's competence; 2) Lack of contradiction to the international norms and laws; 3) Clear ranking of legal act issued in general law system, including law branch, subbranch or institution; 4) Compliance of legal regulation suit and volume with law-making body's competence; 5) Taking into account of Russian Constitution, Constitutional and common federal laws requirements about administrating of different relationships legal regulation.

The legal-normative criterion characterizes a legal nature of law and by-law and allows more precise assessing the possibilities to create the legal framework for different public relationships. The criterion requires carrying out the assessment according to the following parameters: 1) Agreement between content of legal act chosen and Russia and its subjects' competence; 2) A clear verification of appropriate legal system rank for the legal act to be issued including its branch, sub-branch, institution rank; 3) Agreement between legal regulation content and volume and law-making body competence; 4) Taking into account RF constitution, federal constitution laws and federal laws requirements about legal regulation procedure of different relationships.

The law books reported a scientifically under based proposition about a need to make a legal framework for the points to be legally regulated only. This is presented not to result an improvement of the choice of the legal act necessary for relationship regulatory actions. Currently, Russian social, economic and political relations are continuously developing; their social and law-making significance is permanently changing. The legislator has to change quickly his law-making line taking into account the last developing. If there is a range of problems to be legally regulated only then quickly issued law outside this range may require changing and adding it every time a new law is introduced.

2. If the searching indicates that there are objective beginnings to adopt a legal act then its rank shall be in the background. (It may be federal or federal subject rank). This is an important problem because of Russia and its subjects' mutual competence for many regulated relationships. It is understood that federal acts do not allow the provisions of RF subjects' competence to be included. In contra, the subjects' law-making acts must omit the provisions on the points of the federal competence.

Currently, federal law recalls chartering as a form of interaction between federal and regional law-making bodies to issue the legal acts of high quality which had been previously considered by Duma and regarding regulation of Russia and it's subject's mutual competence range is promoted. Regarding the establishment of the federal bodies and authorities' control over the federation subject law-making process, it can be said that such of control is common as less effective as many subject legal acts does not comply the federal legislation as statistics say about that $70 \%$ of subject acts issuing are judicially dismissed. Many of them are not valid due to the incorrect choice of normative act to carry out the legal regulation of different public relationships. This is led by the fact that federal subject interests do not fully foot printed in federal laws, in a great deal of matter. This makes law-making (delegate) bodies and highest state authorities to look for the measures for saving their regional needs.

Therefore, indicating of legal regulation level for every case presents a possibility to determine in a precise manner what of legislative act kind (federal or subject's act) should be chosen.

3. As soon as the need to issue the federal normative act had been adjusted, the determination of its status should be solved whether law, presidential decree or statutory instrument would be issued. It could presume that public relationships to be regulated are always of high social demand and stable. They cover a wide range of relationship subjects interested. The legislative acts are the carcass of state legal system and should be issued on the understanding that they would be long-acting, because "the same problem of state or social life could be hypothetically solved via a surfeit of dozens of legal acts covering the same regulation level.

When assessing public relationships to be regulated via law, it is necessary to adjust what kind of federal law should be issued: it could be constitutional or ordinary law. To make this, a problem to be solved is firstly formulated, then the status of the law to be issued is determined.

The main public and state issues require federal constitutional laws. The latter are issued in accordance with the direct constitutional prescripts. For example, sec. 118 of Constitution stipulates a need to issue the federal constitutional law enshrining in the law the Russian Federation justice system. The sec. 128 contains a similar provision enforcing legally the order of instituting and functioning of Constitutional Court of Russian Federation and Russian Supreme Court (Steunenberg, B., \& Toshkov, D. (2009)).

4. There is the third issue - a choice between municipal and international law. Not all authors draw up international law prevalence. The dualists maintain that as international law cannot address itself to individuals, but only to States, States are free to regulate their internal affairs as they see fit, and that international law exercises little or no control over municipal law. International Law is autonomous and distinct from Municipal/National legal system.

5. The next stage of legal act kind choice to enforce legally the public relationships is the determination of regulation abilities of departmental and municipal legal documents (). 
Solving municipal problems of legal act choice is often carried out during the fighting of different scholars as in Canada. Thus, local interest and freedom are under pressure. "We can begin to do so by building on Pettit's distinction between the idea of freedom as non-interference and freedom as non domination. According to Pettit, the former conception of freedom has been central to liberalism and fails to capture the interests at stake in the idea of freedom as nondomination".

The need to determine regulation abilities arises in the cases when public relationships to be legally regulated serve as limited matters and cover only a certain territory or specified group of subjects. It says that there is a need to issue normative legal acts on the level of federal departments or municipalities.

The departmental (by-law) law-making is by-regulation of public relationships carried out by federal authorized offices of the lowest rank. It is presented by many law-making bodies and requires the legal acts issued by ministries and different departments should comply with the constitutional prescripts, legislative acts, presidential decrees, and government prescriptions. The possibility to adopt them, as a rule, is regulated by laws and other acts of higher ranking. Many departmental by-laws are adopted mandatory under authority of direct prescriptions of law, presidential decrees or governmental prescriptions. On the other hand, accordingly to their ranking, ministries, and departments have a right to issue the legal acts upon their own initiative as well.

6. Globalization is also a problem influencing the choice of legal act, partially, because it raises the question of interaction between laws of different taxonomic levels. One of the key questions for lawyers today becomes to what extent globalization will and can mean harmonization or even uniformization of laws all over the world.

This problem can also regard both by-laws and law-making solutions at municipal level. We presume that by-regulation should be subjected to the harmonization and without prejudice to mandatory uniformization because the latter can annihilate the national, particularly, Russian specifics of this kind of law-making. Although Russian law provisions contradicting the international law should be changed with international ones, it could be presumed that by-regulation has not to be changed with, but added with norms stimulating the participant's good observance. These norms can be provided as modifications changing participants 'responsibilities in the case of their good behavior and wish to observe the law in good practical manner. This aspect is further being developed in another paper.

7. The legal act choice is also complicated by the fact that law-making solution elaborated should contain provisions constituting available legal relationships not only between its norm and legal institutions but also between provisions and law branches including relationships with the whole state legal system.

The legal relationships have to give the legal act issued a clear rank position and legal status.

It should be taken into account that legal normative acts are issued by different law-making bodies differing from each other via rank and competence as well as varied properties. This state of things has a strong influence on available laws and by-laws nature which can often contradict each other. Thus, before legal relationships will have been put in order it is necessary to put the legal acts themselves into suitable system reflecting all relationships with other legal norms and law branches.

Currently, such interaction form between federal and regional law-making bodies as federal law project resolution issued by Duma's conceal on Russia and its subjects' mutual competence points is found. Regarding the federal body's control upon the regional law-making process, its low effectiveness can be still highlighted.

During the law-making process the choice of legal act is also hindered by the fact that act issued should reflect available law relations both between its norms and institutions and all law branches including state legal system. This law must have its rank and status. As a concrete law form, the Code, law or by-law which regulates individual law branch or uniform group of the same public relationships, as well as municipal level law act, can be issued.

\section{CONCLUSIONS}

1. The law-making solutions should be sure in accordance with legal regulation objectives while a reasonable combination of the optional and imperative provisions plays a positive role in these cases. However, imperative provisions abuse leads to the public relationship deterioration, decreasing or even cancel for self-regulating relationships. It over-charges the functional state system facilities as well as shows state's interference in private life. Self-Regulation in private law branch is represented to be maximally developed because the higher self-regulation the fewer laws, orders, regulations, and instructions to be adopted.

2. The legal act choice process is not legally provided so that is fully creative because every time it is carried out in the earmarked form. Every time the choice does not regard abstract but fully certain relationships to be legally ordered.

3. The choice of the legal act necessary for individual cases is performed step-by-step: 1) Firstly, public relationships to be regulated are precisely investigated to decide whether they should be legally provided; 2) After the need had been adjusted, then choice of suitable legal solution was performed. 
4. The public relationships regulation needs are defined via finding out the traits allowing relationships to be legally provided.

5. The choice of judicial form to provide legally the public relationships is associated with the scientific investigation of ability of individual legal act to express in its content the needs inherent to the public relationships so that to form a mechanism of making them order their functioning.

\section{REREFERENCES}

1. Kong, Hoi. (2010). "Something to Talk About: Regulation and Justification in Canadian Municipal Law." Osgoode Hall Law Journal 48.3/4(2010) : 499-541 // http://digitalcommons.osgoode.yorku.ca/ohlj/vol48/iss3/4

2. Kremin A.E., Gulin K.A. (2017). Managing the functioning of small business at the municipal level as a driver of regional economic development // Economic and Social Changes: Facts, Trends, Forecast , 2017, vol. 10, no. 4, pp. 94-110. https://doi.org/10.15838/esc.2017.4.52.5

3. Rybakov V.A. (2015). Pravotvorchestvo v perechodnyj period razvitia prava// Yuridicheskaya technika. 2015. № 9. p. 653-656.

4. Solovyev S.G. (2012). Ponyatie predmeta prav. reg i ego vsaimosvyaz's drugimi yuridicheskimi kategoriyami// Vestnik Permskogo Universiteta, 2012. № 1 (15). pp.47-48.

5. Werner Menski. (2006). Comparative Law in global context. The legal systems of Asia and Africa ( 2006). https://doi.org/10.1017/CBO9780511606687

6. Hojati, M., Rezaei, F., \& Iravani, M. R. (2014). Study the Effects of Cognitive and Metacognitive Learning Strategies to Increase Student Motivation and Probation of Sama Vocational Schools Probation Students of Najaf Abad Branches in School Year 2013-2014, UCT Journal of Management and Accounting Studies, 2(2): 35-40

7. Sultanbekova, Z., Yergobek, K., Atemova, K., \& Koshenova, T. (2018). Role of Works of Kazakh Writer Dulat Issabekov in Modern National. Opción, 34, 110-132.

8. Matandare, M. A. (2018). Botswana Unemployment Rate Trends by Gender: Relative Analysis with Upper Middle Income Southern African Countries (2000-2016). Dutch Journal of Finance and Management, $2(2), 04$. https://doi.org/10.20897/djfm/3837

9. Nazoktabar, H., \& Tohidi, G. (2014). Shanty Town and Socio-Cultural Problems in Sari City, Iran, UCT Journal of Social Sciences and Humanities Research, 2(2): 29-31.

10. Kuznetsova, E. (2019). Probabilistic Ideas and Methods in Undergraduate Mathematics: Axiological Aspects. International Electronic Journal of Mathematics Education, 14(2), $363-373$. https://doi.org/10.29333/iejme/5720

11. Lima, A., Mendes, D., \& Paiva, S. (2018). Outdoor Navigation Systems to Promote Urban Mobility to Aid Visually Impaired People. Journal of Information Systems Engineering \& Management, 3(2), 14. https://doi.org/10.20897/jisem.201814

12. Fischer-Lescano, A., \& Teubner, G. (2019). Regime-collisions: the vain search for legal unity in the fragmentation of global law. In Critical theory and legal autopoiesis. Manchester University Press. https://doi.org/10.7765/9781526139948.00018

13. Steunenberg, B., \& Toshkov, D. (2009). Comparing transposition in the 27 member states of the EU: the impact of discretion and legal fit. Journal of European Public Policy, 16(7), 951-970. https://doi.org/10.1080/13501760903226625

14. Vereshchetin, V. S. (1996). New Constitutions and the old problem of the relationship between international law and national law. Eur. J. Int'l L., 7, 29. https://doi.org/10.1093/oxfordjournals.ejil.a015502

15. Tushnet, M. (1972). Lumber and the Legal Process. Wis. L. Rev., 114.

16. Chambliss, W. J., \& Seidman, R. B. (1971). Law, order, and power (p. 3). Reading, MA: Addison-Wesley.

17. Higgins, R. (1970). The place of international law in the settlement of disputes by the Security Council. American Journal of International Law, 64(1), 1-18. https://doi.org/10.2307/2198614

18. Haines, C. G. (1922). General Observations on the Effects of Personal Political and Economic Influences in the Decisions of Judges. Ill. LR, 17, 96.

19. Senden, L. A. (2005). Soft law, self-regulation and co-regulation in European law: where do they meet?. Available at SSRN 943063.

20. Teubner, G. (2019). Global Bukowina: legal pluralism in the world society. In Critical theory and legal autopoiesis. Manchester University Press. https://doi.org/10.7765/9781526139948.00017

21. Armstrong, K. A. (1998). Legal integration: theorizing the legal dimension of European integration. JCMS: Journal of Common Market Studies, 36(2), 155-174. https://doi.org/10.1111/1468-5965.00104

22. Jackson, J. H. (1992). Status of treaties in domestic legal systems: a policy analysis. American Journal of International Law, 86(2), 310-340. https://doi.org/10.2307/2203236

23. Caron, D. D. (2002). The ILC articles on state responsibility: the paradoxical relationship between form and authority. American Journal of International Law, 96(4), 857-873. https://doi.org/10.2307/3070682

24. Curtin, D., \& Leino, P. (2017). In search of transparency for EU law-making: Trilogues on the cusp of dawn. Common market law review, 54(6), 1673-1712. 
25. Lindsay, J. M. (1999). Creating a legal framework for community-based management: principles and dilemmas. UNASYLVA-FAO-, 28-34.

26. Kirchner, C. (2008). The Power of Rational Choice Methodology in Guiding the Analysis and the Design of Public International Law Institutions-Concluding Remarks. U. Ill. L. Rev., 419. 